\title{
ОБЯЗАТЕЛЬНЫЕ ПРИЗНАКИ ОБЪЕКТИВНОЙ СТОРОНЫ СОСТАВА ПРЕСТУПЛЕНИЯ ПРИ ПОРЧЕ ЗЕМЛИ
}

\section{MUST OBJECTIVE PARTY OF THE CRIME AT LAND DAMAGE}

\section{S. Malkov \\ A. Agafonov}

Summary. In this article, we carry out a doctrinal and legal analysis of the mandatory features of such an element of the corpus delicti in the case of land damage, as its objective side. With the help of the obtained and scientifically determined categorical concepts, we tried to analyze both the content itself and the types of the main signs of the objective side of the crime, provided, in turn, in Article 254 of the Criminal Code of the Russian Federation ("Damage to the land"). At the same time, we identified and further analyzed a number of rather problematic issues, in our opinion. In the article offered to the readers, the authors ' own vision of solving the problems we have identified is also offered.

Keywords: crime, crime, socially dangerous act, socially dangerous consequences, causal, criminal protection, damage, harm, way of committing a crime, land poisoning, land pollution.

\author{
Мальков Сергей Михайлович \\ К.ю.н., дочент, Сибирский юридический институт \\ МВД России \\ Serqeymalkov@mail.ru \\ Агафонов Александр Владимирович \\ К.ю.н., Сибирский юридический институт МВД \\ Poccuu \\ aleksandravagafonov@yandex.ru
}

Аннотация. В настоящей статье нами осуществляется доктринально-правовой анализ обязательных признаков такого элемента состава преступления при порче земли, как его объективная сторона. С помощью полученных и научно обусловленных категориальных понятий мы постарались проанализировать как само содержание, так и виды основных признаков объективной стороны состава преступления, предусмотренного, в свою очередь, в ст. 254 УК РФ («Порча земли»). При этом нами были выявлены и подвергнуты в дальнейшем анализу и ряд довольно проблематичных, по нашему мнению, вопросов. В предложенной читателем статье также предлагается и собственное видение авторов разрешения обозначенных нами проблем.

Ключевые слова: преступление, состав преступления, общественно опасное деяние, общественно опасные последствия, причинная связь, объект уголовно-правовой охраны, ущерб, вред, способ совершения преступления, отравление земли, загрязнение земли.

циями мнение о том, что под объективной стороной состава преступления следует понимать именно характеристику действующим уголовным законодательством России внешних, то есть вполне доступных для восприятия любым правоприменителем, объективно существующих в окружающем нас материальном мире, признаков уголовно наказуемого общественно опасного деяния [2, с. 81], где к обязательным признакам анализируемого нами элемента состава преступления все известные российские ученые-правоведы относят только и именно само общественно опасное деяние.

Однако само понятие этого деяния в действующем российском уголовном законодательстве не раскрывается. Более того, там выделяются и закрепляются всего лишь две формы фиксации последнего, а именно преступные действия и преступное бездействие. УК РФ перечисляет эти варианты человеческого противоправного поведения как альтернативные.

При этом действия представляют собой, по мнению большинства российских исследователей, либо некое 
движение одного из органов человеческого организма, направленное на достижение вполне определенной виновным лицом цели, либо целую систему отдельных телодвижений человека, объединенных тем не менее единой целью причинения вреда охраняемым и регулируемым уголовным законодательством общественным отношениям, образующих собой саму систему социально негативного поведения, то есть систему вполне противоправной уголовно наказуемой деятельности [1, с. 226].

Впрочем, подобный вред уголовным правоотношениям вполне реально может быть достигнут не только в результате внешне активного действия, а также и путем пассивного поведения виновного лица. Однако отнюдь не любое бездействие будет признано уголовно наказуемым. Помимо общего требования о возможности для физического лица в каждой конкретной ситуации совершить вполне определенное действие, преступник должен быть обязан совершить такое действие уже в силу прямого указания на то законом.

Явно дискуссионным ныне признается современным научным правовом сообществом России вопрос о том, ограничивается ли преступное действие только действиями самого физического лица либо оно включает в себя также и силы природы или иных физических лиц, которые виновное лицо может использовать для достижения явно необходимого ему, но преступного по нормативно правовому содержанию результата.

Заканчивается уголовно наказуемое действие либо в момент прекращения самого общественно опасного поведения виновного, направленного при этом на достижение необходимого ему преступного результата в виде формального вреда или материального ущерба, либо в момент непосредственного наступления общественно опасных последствий, которые рассматриваются в российском законодательстве именно как результат подобной деятельности [1, с. 228].

Под общественно опасными последствиями следует понимать, по общепринятому мнению, изменения объекта уголовно-правовой охраны, имеющие вполне объективно существующий социально негативный характер и возникшие именно в результате совершения конкретного преступного деяния [3, с. 169].

Эти изменения объекта уголовных правоотношений могут материализоваться в дальнейшем либо в форме вполне конкретного материального ущерба, либо в форме иного социально значимого вреда, для определения которого имеются весьма четко обусловленные критерии, а также комплексного вреда охраняемым российским уголовным законодательством объектам (социального, психического, организационного).
Между уголовно наказуемым деянием и наступившими именно в результате его совершения социально негативными последствиями должна быть установлена причинная (то есть прямая причинно-следственная) связь (необходимо при этом помнить, что косвенная следственно-причинная связь уголовную ответственность не вызывает).

Под этой связью вполне традиционно понимают объективно существующую и функционирующую в окружающем нас материальном мире связь между преступным деянием и наступившими в результате совершения последнего общественно опасными последствиями, наличие которой является не только обязательным, но и вполне достаточным условием для привлечения виновного лица к уголовной ответственности, если состав настоящего преступления по конструкции объективной стороны последнего относится именно к материальным.

Применительно к уголовно-правовой норме, предусмотренной в ст. 254 УК РФ, общественно опасное деяние как обязательный признак состава преступления в действующем российском уголовном законодательстве довольно четко и однозначно конкретизировано.

С объективной стороны деяние характеризуется совершением хотя бы одного из прямо перечисленных В диспозиции ч. 1 ст. 254 УК РФ действий (или бездействием):

а) отравлением земли вредными продуктами хозяйственной или иной деятельности;

б) загрязнением земли этими продуктами;

в) иной порчей земли вредными продуктами хозяйственной или иной деятельности.

Причем все вышеперечисленные противоправные деяния должны быть совершены виновным лицом именно в результате его нарушения правил обращения с удобрениями, стимуляторами роста растений, ядохимикатами и иными опасными химическими или биологическими веществами при их опосредованном хранении, использовании или транспортировке.

Таким образом, следует резюмировать, по нашему мнению, и тот явно безусловный факт, что совершить анализируемое преступление можно лишь деянием в форме именно бездействия. Последнее, в свою очередь, предполагает фиксацию трех вполне самостоятельных способов совершения настоящего преступления. В этом случае способ совершения преступления будет также признан в качестве вполне обязательного признака объективной стороны состава анализируемого нами преступного деяния. 
Кроме того, мы явно вправе зафиксировать при анализе основных признаков объективной стороны данного состава и такие его обязательные признаки, как общественно опасные последствия в виде причинения вреда здоровью человека либо уничтожение или существенное повреждение как природных объектов, так и ресурсов, и прямую причинную связь между совершенным уголовно наказуемым деянием и наступившими в результате совершения последнего социально значимыми негативными последствиями.

Отсюда неизбежно следует, что состав анализируемого преступления по конструкции объективной стороны относится к материальным.

Правила, опосредованная ссылка на которые имеется в ч. 1 ст. 254 УК РФ, в свою очередь, отражены и довольно четко зафиксированы в различного рода законодательных актах, регулирующих разные сферы социального бытия современного российского общества. При этом они напрямую связаны с регламентацией, регуляцией и запретом гражданско-правового оборота удобрений, стимуляторов роста растений, ядохимикатов и иных опасных химических или биологических веществ.

Под удобрениями большинство современных российских правоприменителей вполне традиционно понимают либо органические, либо минеральные вещества, содержащие в своем составе все необходимые для растений элементы питания. Исходя из особенностей их химического состава, все удобрения подразделяются на два основных вида, а именно органические и неорганические (минеральные). При этом некоторые российские исследователи считают, что вполне имеют место быть и так называемые бактериальные удобрения.

К стимуляторам роста растений, по мнению ряда современных российских правоведов, следует относить либо естественно возникшие, либо синтетически созданные вещества, которые существенно ускоряют фитогенез растений, а, следовательно, весьма положительно влияют и на рост и развитие последних.

Современные российские ученые-химики считают, что в качестве ядохимикатов необходимо признавать пестициды, то есть такие химические или биологически активные препараты, которые изначально созданы для уничтожения вредителей сельскохозяйственных растений, борьбы с их заболеваниями, уничтожения сорняков и иных социально вредных растений, вредителями законсервированной сельскохозяйственной продукции, домашними вредителями, наружными паразитами домашних животных, а также для предварительного удаления листьев растений, подлежащих в последующем сбору при уборке урожая (дефолианты), и для предварительной предуборочной сушки самих этих растений (десиканты).

Некоторые российские исследователи относят к пестицидам и регуляторы роста растений, разделяя их при этом на акарициды, альгициды, антигельминты, антирезистенты, антисептики, антифидинги, арборициды, аттрактанты, бактерициды, гербициды, дефолианты, репелленты, стимуляторы роста растений, фунгициды и т.д.

Пестициды характеризуются и явно токсичными, а, следовательно, и социально опасными свойствами. Как следствие последнего, они могут концентрироваться не только в объектах окружающей нас природной среды, но и в самом организме человека, приводя порой к социально негативным последствиям в виде либо разрушения и уничтожения первых, либо в заболевании и неизбежной смерти вторых.

Таким образом, согласно действующему российскому законодательству с пестицидами вправе и могут работать только специально обученные люди, причем явно не моложе восемнадцати лет и не старше установленного законом возраста (женщины - пятьдесят, мужчины - пятьдесят пять лет) с помощью специально приспособленных машин и аппаратов, используя при этом специально созданные или приспособленные хранилища.

К иным опасным химическим или биологическим веществам следует, по общепринятому мнению, относить именно те химические или биологические вещества, которые не отражены ни в одной из вышеперечисленных нами групп. Более того, к ним явно относятся и те, которые созданы и для иных целей, однако применение последних в силах вызвать причинение либо определенного вреда, причем не только здоровью, но и жизни человека, либо реального ущерба окружающей нас природной среде.

Таким образом, правила обращения с удобрениями, стимуляторами роста растений, ядохимикатами, иными опасными химическими или биологическими веществами будут признаваться подвергнутыми нарушению, если в результате действия виновного лица концентрация вредных веществ в почвенном покрове явно превышает нормативы предельно допустимого; виновным лицом использованы в своей повседневной профессиональной деятельности химические вещества или токсичные химические препараты, не нашедшие место в списке разрешенных к использованию действующим законодательством; виновным лицом использованы 
прямо запрещенные в России агрохимикаты, при этом эти химикаты хранятся вне специально приспособленных для этой цели хранилищ или в отношении них осуществляется транспортировка путем использования не специально предназначенного транспорта; работники, не обладающие при этом специфической профессиональной подготовкой, тем не менее были допущены к работе с пестицидами ограниченного использования и т.п.

В свою очередь, указанные нами правила включают в себя:

а) определенные стандарты обращения с вредными и опасными веществами при их дальнейшем хранении;

б) определенные стандарты использования этих веществ;

в) определенные стандарты при транспортировке последних.

Под обращением, по мнению большинства ведущих российских ученых-правоведов, явно необходимо понимать все виды ныне действующей экономической деятельности с указанными нами веществами, но исключительно в рамках их хранения. Отсюда вполне обоснованной следует признать и мысль о том, что хранение вредных и опасных веществ неизбежно предполагает и их нахождение в каком-либо, но вполне конкретном месте.

Необходимо в целом согласиться и с мнением о том, что под использованием этих веществ понимается реальное применение последних, причем как для промышленного производства сельскохозяйственных или иного рода работ, так и для осуществления иных социально значимых целей.

Таким образом, состав анализируемого преступного деяния вполне может иметь место, когда:

а) налицо отравление, загрязнение или иная порча земли;

б) отравление, загрязнение, иная порча происходят не в результате использования виновным лицом удобрений, стимуляторов роста растений, ядохимикатов и иных опасных веществ, а именно в результате использования вредных продуктов хозяйственной или иной подобного рода деятельности, которые образуются именно вследствие нарушения вполне определенных правил обращения с этими веществами;

в) обращение с ними, в свою очередь, подразделяется на хранение, использование и транспортировку указанных нами веществ;

г) отравление, загрязнение и иная порча земли вредными продуктами хозяйственной или иной подобного рода деятельности неизбежно повлекли за собой причинение вреда здоровью человека или окружающей нас природной среде.

Под отравлением земли, по мнению большинства современных российских исследователей, явно необходимо понимать весьма существенную степень пресыщения верхнего почвенного слоя земли на уровне его загрязнения ядохимикатами или токсичными продуктами антропогенной деятельности, в результате чего использование земли может вызвать в дальнейшем либо неизбежные заболевания или даже гибель населяющих ее людей, либо повреждение, либо полное уничтожение окружающей их природной среды.

Под загрязнением земли, видимо, следует понимать значительное ухудшение в результате экономической или иной подобного рода деятельности человека качества земель любой категории, характеризующееся при этом либо появлением, либо увеличением химических веществ или уровня радиации по сравнению с их ранее фиксирующими значениями.

В современном российском экологическом законодательстве общее понятие порчи земли трактуется как вполне равнозначное таким понятиям, как уничтожение или существенное повреждение ее почвенного или плодородного слоя. Таким образом, под порчей земли понимают полное или частичное ее разрушение, вследствие чего пользователем земли фиксируется либо существенное ухудшение, причем как физических, так и биологических ее свойств, либо значительным понижением социально-экономической ценности земель в результате непродуманного осуществления антропогенной деятельности или непринятия мер по предотвращению природных происшествий [4].

Следовательно, под понятие «иной порчи земли» подпадает ее дальнейшие захламление, засоление, заражение и т.д., где захламление земли - это поверхностная и иная утилизация использованных предметов и отходов хозяйственной и иной человеческой деятельности в неустановленных законом местах.

Засоление земли, видимо, может означать весьма существенную концентрацию в ней легкорастворимых в воде минеральных солей (хлоридов, сульфатов, карбонатов натрия, кальция и магния), а, следовательно, и неизбежный перевод засоленной земли в одну из следующих категорий почв: солончаки (сильно засоленные), солончаковые (менее засоленные) и солонцы (засоленные явно ниже пахотного слоя).

Далее, заражение земли, по общепринятому мнению, может выражаться в привнесении в нее снаружи 
возбудителей бактериальных, паразитарных, инфекционных и иных заболеваний.

Допустимый уровень загрязнения при этом признается содержанием в почвенном слое химических веществ, не превышающим при этом их предельно допустимых концентраций (ПДК) или ориентировочно допустимых концентраций (ОДК). Таким образом, если в результате непродуманной до конца антропогенной деятельности налицо вполне допустимый уровень загрязнения почв, то подобная порча земли не подпадает под признаки состава преступления, предусмотренного ст. 254 УК РФ.

Уголовная ответственность за порчу земли наступает именно от использования виновным лицом вредных продуктов хозяйственной или иной деятельности. Хозяйственная деятельность есть человеческая деятельность в любой сфере современной российской экономики. Под иной деятельностью, видимо, необходимо понимать все остальные виды социально полезной деятельности человека.

Осуществление такого рода противоправных деяний в зоне экологического бедствия или в зоне чрезвычайной экологической ситуации подлежит в дальнейшем квалификации по ч. 2 ст. 254 УК РФ.

В качестве обязательного условия применения к виновному лицу уголовной ответственности по ст. 254 УК РФ признается причинение в результате совершенного им противоправного деяния вреда здоровью человека или окружающей среде.

Под вредом здоровью человека в целом российским правоприменителем вполне традиционно понимается причинение хотя бы одному потерпевшему тяжкого, средней тяжести или легкого вреда здоровью, расстройство здоровья, временная или постоянная утрата трудоспособности.

Уголовно наказуемое деяние, повлекшее за собой неизбежную смерть человека, признается российским правоприменителем особо квалифицированным составом анализируемого преступления.

Вред окружающей нас природной среде, то есть флоре и фауне, может проявляться в уничтожении или гибели представителей флоры или фауны, приведении почвенного слоя в такое состояние, которое изначально непригодно для дальнейшего использования в сельском хозяйственном производстве или для осуществления экологических функций.

Анализируемое нами противоправное деяние, следовательно, уже выступает в качестве последствия. Таким образом, применительно к составу такого преступления, как порча земли, вполне допустимо говорить о последствиях двух порядков.

В связи с этим прямая причинно-следственная связь российским правоприменителем должна фиксироваться не только между нарушением правил, указанных нами выше, и последующей порчей земли, но также и между порчей земли и причинением вреда здоровью человека или окружающей среде.

Следовательно, мы считаем вполне доказанным постулат о том, что состав преступления, предусмотренный в ст. 254 УК РФ, по конструкции своей объективной стороны относится не только к материальным, но и к составам преступления с альтернативными признаками объективной стороны, каждая из которых может быть совершена только в форме преступного бездействия.

\section{ЛИТЕРАТУРА}

1. Кудрявцев В.Н. Объективная сторона преступления / В.Н. Кудрявцев. - М.: Госюриздат, 1960. - 244 с.

2. Курс уголовного права. Общая часть. Т. 1: Учение о преступлении / под ред. Н.Ф. Кузнецовой и И.М. Тяжковой. — М.: Зерцало-М, $2002 .-624$ с.

3. Назаренко, Г.В. Уголовное право. Общая часть: курс лекций / Г.В. Назаренко - М.: Ось-89, 2005. - 256 с.

4. Уголовное право Российской Федерации. Общая часть: учебник. Практикум / под ред. А.С. Михлина.— М.: Юристь, 2004.— 494 с. 